\title{
The role of accounting accruals for the prediction of future cash flows: evidence from Spain
}

\author{
Laura Arnedo • Fermín Lizarraga • \\ Santiago Sánchez
}

Received: 10 September 2009 / Accepted: 12 May 2011 / Published online: 17 June 2011

(C) The Author(s) 2011. This article is published with open access at SpringerLink.com

\begin{abstract}
The aim of this study is to determine whether accruals have information value beyond that provided by isolated current cash flows for the prediction of future cash flows. Using a sample of 4,397 Spanish companies (mostly privately held), we estimate in-sample regressions of future cash flows on isolated current cash flows and on accrual-based earnings. We then find that the out-of-sample prediction errors provided by the accrual-based earnings model are significantly lower than those obtained with the cash flows model. We also regress the decrease in prediction errors brought about by the addition of accruals on a set of firm-specific circumstances where accounting manipulation is expected. In all cases the decrease in prediction errors is significantly affected in the hypothesized direction.
\end{abstract}

Keywords Cash flows $\cdot$ Accruals $\cdot$ Prediction

\section{JEL Classification M41}

\section{Introduction}

The two main accounting standards boards (FASB 1978; IASB 1989) agree on the superiority of accrual-basis accounting over the cash basis to provide summary indicators of a firm's performance. According to these boards, accrual-based earnings

L. Arnedo · F. Lizarraga · S. Sánchez

Business Department, Public University of Navarra,

Campus Arrosadía s/n, 31106 Pamplona, Spain

F. Lizarraga $(\varangle)$

Departamento de Gestión de Empresas, Universidad Pública de Navarra,

Campus Arrosadía s/n, 31006 Pamplona, Spain

e-mail: ferlizar@unavarra.es 
generally provide a better indication of the timing and uncertainty of prospective cash flows than the information limited to cash receipts and payments. Accruals, therefore, are essential to accomplish the primary objective of financial reporting. They enhance the relevance for future cash flows prediction, reduce costs introduced by information asymmetries and contribute to a better allocation of economic resources (see SFAC, No 1, FASB 1978).

The aim of this study is to determine whether, for Spanish companies, accrual-based earnings have information value beyond that provided by isolated current cash flows for the prediction of future cash flows. Given that the accrual process is the result of a trade-off between relevance and reliability (Dechow 1994), one of the most important questions in accounting research is whether accruals really provide a better summary measure of firm performance. Although US researchers have already provided empirical support for this role, it is yet to be confirmed whether this evidence holds for a code-law country like Spain. Spanish stock markets are far less developed than those of the US, ownership is highly concentrated and external finance is obtained mostly from banks. This leads to different agency problems and calls into question the interest of accounting information for external users. Furthermore, the role of accounting accruals for the prediction of future cash flows is bound to differ across public and private firms and, although the former are likely to be more similar to Anglo-Saxon firms, most Spanish companies are privately held.

The main motivation for our study comes from the need to provide Spanish investors and creditors with empirical evidence on the beneficial role of accruals for future cash flows prediction. In Spain, most accounting research usually takes for granted that accruals provide relevant information to better assess a firm's future cash flows generation. However, there is little empirical evidence that supports this, especially for private firms. Accounting regulation and enforcement make the Spanish setting an interesting case study. The Spanish legal model of accounting took advantage of the reform that resulted from the implementation of EU Directives to approach the Anglo-Saxon model. Since 1990, Spain has had accounting standards of sufficiently high quality to expect accruals to provide value-relevant information. Enforcement mechanisms, nevertheless, are still ineffective in Spain. The literature highlights that the quality of accruals is not only a matter of the quality of accounting standards but also of how these standards are enforced. Empirical evidence that earnings quality is significantly lower in countries with poor enforcement mechanisms (Leuz et al. 2003) and especially in private firms (Burgstahler et al. 2006) reduces confidence in the Spanish reporting model and calls for an empirical evaluation of the information content of accruals. This is, therefore, the primary purpose of our study.

Using a sample of 4,397 companies (mostly privately held), we test the role of accruals for the prediction of future cash flows (Hypothesis 1) by estimating in-sample (1997-2001) regressions of future cash flows (up to 4 years ahead) on isolated current cash flows (cash flows model, 1) and on accrual-based earnings (accrual-based model, 2) and, subsequently, looking for differences in the out-of-sample prediction errors between the two models. Overall, our results are consistent with the argument that accruals add relevant information for the prediction of future cash flows, that is, that the prediction errors provided by an accrual-based earnings model are significantly lower than those obtained with isolated current cash flows. This predictive 
ability increases if we include accruals in the disaggregated fashion (five components) suggested by Barth et al. (2001). On the other hand, we also find that the role of accruals for the prediction of future cash flows is significantly moderated in firmspecific situations where managers are expected to make a more opportunistic use of accounting discretion. For each of the variables used to proxy for these situations (small size, privately held, need for new finance and high level of subjectivity of the firms' accruals), prediction errors decrease significantly in the hypothesized direction.

Our paper adds to the accounting literature by providing evidence that accruals permit a better prediction of future cash flows, thus contributing to a better allocation of resources. We are not aware of any study that has, so far, proved the out-of-sample ability of accruals to predict future cash flows in a representative sample of Spanish firms, that is, using a corresponding proportion of both public and private firms. We also find evidence of a significant moderating effect of accounting manipulation that lowers the informational value of accruals below their otherwise attainable levels. This suggests that, if Spanish regulators do not improve the enforcement of accounting standards, the accrual-based information will not be of high quality. Finally, as in Barth et al. (2001), we find that disaggregating accruals into their major components significantly increases their predictive ability. The rest of the paper is organized as follows. Section 2 reviews prior research on the role of accruals for the prediction of future cash flows. Section 3 focuses on the Spanish case and includes the two hypotheses of our study. Section 4 describes the research methodology and the sample and we present our empirical results in Sect. 5. Finally, the summary and conclusions appear in Sect. 6.

\section{Prior research on the role of accruals: literature review}

The benefits of accruals are a direct consequence of increasingly sophisticated accounting regulations. Accruals, nevertheless, are also fraught with measurement error due to the assumptions underlying their determination and the discretion allowed under GAAP. Accrual-based accounting standards involve judgment as they require estimations about future events that are not considered in current cash flows. Although subject to unintentional error, these estimations signal private information and are, thus, expected to be value relevant, that is, to increase users' accuracy in assessing the present value of future cash flows. Managers, however, can use accounting discretion opportunistically to serve other and less benign interests by introducing estimation noise that makes reported earnings misleading about the firm's economic performance. ${ }^{1}$

Given that the accrual process is the result of a trade-off between relevance and reliability (Dechow 1994), one of the most important questions in accounting research is whether accruals really provide a better summary measure of firm performance. It is essential to provide users with empirical evidence that supports the assertions of the FASB/IASB about this role. However, although one might expect investors and

\footnotetext{
${ }^{1}$ Decisions such as assets write-downs, research and development capitalization, the setting up of provisions, etc. are based on managers' estimations of the expected future cash flows.
} 
creditors to demand this empirical evidence, they often accept or reject the role of accruals without having received it. This is the case in Spain. ${ }^{2}$

Prior Anglo-Saxon literature has generated a vast number of studies addressing the incremental information content of accruals. Much of this evidence is price-based, that is, it relies on studies that substitute stock prices for real future cash flows (more difficult to obtain). These studies are widely consistent with the hypothesis that accruals are value relevant in the marketplace. Strictly speaking, market prices are the outcome of how investors, as external users, perceive accruals. These prices, however, will not map into future cash flows if the behaviour of stock markets is not efficient. Accordingly, stock prices might not be the most suitable reference for testing the benefits of accruals. Evidence of these benefits for real future cash flows prediction would serve as a guide to investors in the subsequent pricing of accruals. ${ }^{3}$

Alternative, non-price, studies provide evidence of the ability of accruals to predict future cash flows. Several studies document that, for a given year, accruals show a strong positive association with years-ahead cash flows after regressing cash flows in period $t+i$ on cash flows and accruals in period $t$ (see Kim and Kross 2005). Barth et al. (2001) and Al-Attar and Hussain (2004) further demonstrate that decomposing accruals into five individual reported items (and giving them separate coefficients in the estimations) provides significant additional explanatory power over and above current cash flows and aggregated accruals. In-sample regressions, however, are not prediction tests and may even provide misleading inferences concerning prediction. ${ }^{4}$

A parallel line of studies uses out-of-sample testing as a way of solving the important problems inherent in association tests. Although the earliest out-of-sample studies do not support the role of accruals for the prediction of future cash flows, more recent papers do (Brochet et al. 2008). Yoder (2007) extends Barth et al.'s (2001) evidence by finding that prediction errors using a disaggregated accrual-based model are significantly lower than those using either an isolated current cash flows model or an aggregated accruals model. Overall, and with the exception of Lev et al. (2009), recent US evidence provides support for the value of accruals in directly predicting future cash flows.

\section{The role of accruals in the Spanish reporting framework: hypotheses development}

Accounting, like other social disciplines and human activities, is largely a product of its environment. The extension of the Anglo-Saxon empirical support for the bene-

\footnotetext{
2 There is evidence that, in Spain, some banks adjust net income to eliminate the effect of the most subjective accruals (Ansón et al. 1997).

3 Kim and Kross (2005) empirically find that while the role of earnings in pricing securities deteriorates over time there is an increase in the ability of earnings to forecast future cash flows.

4 The results of the so-called association studies do not necessarily suggest an incremental ability of accruals to forecast future cash flows. The superiority in goodness of fit tests (e.g. $R^{2}$ ) does not necessarily translate into superiority in predictive ability because the model can 'overfit' the data. The functional relationship may change over time and, therefore, the association found in year $t$ may not be useful in making out-of-sample predictions in year $t+i$.
} 
fits of accruals to the Spanish case is yet to be confirmed because of the well-known institutional differences between the US and Spain in terms of both corporate governance and accounting regulation and enforcement. Unlike in the US, banks are a major source of finance in Spain (stock markets are far less developed) and there is high ownership concentration. This leads to different agency problems and calls into question the interest of managers (users) in providing (demanding) high quality accounting information. Furthermore, the role of accruals for the prediction of future cash flows is bound to differ across public and private firms and, although the former are likely to be more similar to Anglo-Saxon firms, most Spanish companies are privately held. Agency problems and the mechanisms employed to solve them among private companies are different from those available for public companies. ${ }^{5}$ In a bank-based financial system like the Spanish one, close monitoring through private information channels may substitute for monitoring based on accounting information and financial reports might be formulated with other intentions than predicting future cash flows (e.g. taxation or dividend policy purposes).

Accounting regulation and enforcement is a further important determinant of the quality of financial reporting and, therefore, of the value relevance of accruals. In Spain, a major reform of accounting law took place with the implementation of the Fourth, Seventh and Eighth EU Directives on company law through the Acts of 1988 and 1989 and a revision in 1990 of the General Accounting Plan. Unlike other EU members that tried to preserve their status quo in accounting, Spain used the reform that resulted from this implementation to approach the Anglo-Saxon model in terms of tax alignment and policy regulation. This more equity-oriented view of accounting rules implies that, since 1990, Spanish accounting standards are of sufficient quality to expect value relevance in the companies' accrual-based outcomes. ${ }^{6}$

Adopting high quality standards is a necessary but not sufficient condition for high quality information. The quality of accrual-based earnings is not only a matter of the quality of accounting standards but also of how these standards are enforced and, despite the relative increase in the quality of standards, a parallel increase in the efficiency of enforcing them has not yet been achieved in Spain. Investor protection rights are much weaker than in the Anglo-Saxon countries (La Porta et al. 1998) and litigation risk is almost inexistent for firm managers and auditors. ${ }^{7}$

In Spain, most accounting research usually takes for granted that accruals provide relevant information to better assess a firm's future cash flows generation. However, there is little empirical evidence that supports this, especially among private firms,

\footnotetext{
5 Although, during our period of study, public and private firms in Spain have to comply with the same accounting standards, the two groups respond differently to institutional factors and have different enforcement mechanisms.

6 Oliveras and Puig (2005) suggest that Spain occupies an intermediate position between the most traditional Continental European countries (Germany, France) and the most typically Anglo-Saxon (the US and the UK) in the degree of tax influence in accounting. Hung (2001) creates a 0-1 accrual-based ranking where Anglo-Saxon countries offer values of over 0.8 while Continental European countries like Germany and Italy are just over 0.4. Although catalogued as Continental, Spain's value of 0.77 is closer to the Anglo-Saxon countries than to its European counterparts.

7 In the 15 years since the EU reform, no auditor has been required to pay damages to any third party by a court of law (Ruiz et al. 2004).
} 
despite their macroeconomic significance. Both Gabás and Apellániz (1994) and Giner and Sancho (1996) provide some evidence that accruals display a significant association with future cash flows, but neither of them tests out-of-sample prediction or extends the analysis beyond the scope of public firms. Working with stock market prices, Íñiguez and Poveda (2008) find that strategies based on accruals help specific investors to generate positive abnormal returns, which is evidence of their economic value. ${ }^{8}$ As for private firms, only two studies provide some indirect evidence of the value relevance of accruals. Gill de Albornoz and Illueca (2007) show that Spanish bank lenders perceive accruals as valuable information to set the interest rates charged to their clients, although only for large firms. ${ }^{9}$ In the failure prediction area, Lizarraga (1997) offers evidence that accrual-based ratios (e.g. profitability ratios) are a much better predictor of bankruptcy than those built upon cash flows.

Given the above-mentioned arguments and the lack of clear evidence, it is yet to be seen to what extent preparers' incentives, accounting standards and enforcement mechanisms interact to produce high quality accrual-based information in Spain. We still think that, despite their possible counter effects, accruals are value relevant for the prediction of future cash flows. Our first hypothesis is, then:

Hypothesis 1 In Spain, a model that includes current cash flows and accruals will better predict future cash flows than a model that includes only current cash flows.

Corporate governance and oversight systems are critical to secure compliance with accounting standards. The lack of competent enforcement of these standards encourages managerial opportunism with a potential mitigating effect on the role of accruals. Gill de Albornoz and Alcarria (2003), Gallén and Giner (2005) and Mora and Sabater (2008) provide empirical support for the opportunistic use of accruals by Spanish public firms. As for private firms, Arnedo et al. (2007) show that they also engage in accruals' manipulation and Gill de Albornoz and Illueca (2007) find that Spanish bank lenders penalize this manipulation by demanding a higher cost of debt. International studies provide substantial evidence of the higher degree of earnings management in code-law countries (Hung 2001; Leuz et al. 2003) and especially among private firms (Burgstahler et al. 2006). ${ }^{10}$ Providing evidence of a significant mitigating effect of earnings manipulation on the role of accruals for the prediction of future cash flows would draw attention to the need to strengthen the enforcement mechanisms over the financial reporting system. Testing Hypothesis 1 , however, is not sufficient for this purpose because its non-rejection does not imply that accruals are free from manipulation

\footnotetext{
8 These authors, however, find that these strategies are significantly more common in the UK and Germany than in Spain.

${ }^{9}$ For these authors, small and medium-size companies use alternative sources like asset-based lending or relationship lending because of the financial institutions' lower trust in the accounting information.

${ }^{10}$ Hung (2001) finds that the quality of accrual accounting decreases with managerial propensity to manipulate which, in turn, is a consequence of the poor shareholder protection typical of code-law contexts. He highlights the importance of considering shareholder protection when formulating accounting policies related to accruals. Leuz et al. (2003) examine systematic differences in a set of earnings management measures across 31 countries and confirm that being an Anglo-Saxon country and one with high investor protection significantly explains a lower engagement in earnings manipulation.
} 
or that they are being used optimally. The quality of accruals is inversely proportional to the opportunistic discretion exerted by managers and, though significantly better than the cash basis, the accrual basis could still perform well below its possibilities. An overall analysis (Hypothesis 1) does not make it possible to demonstrate whether, in certain cases, the predictive ability of accruals is lower than expected. For this reason, we test, as our second hypothesis, whether the role of accruals in Spain is substantially constrained in firm-specific situations where a high level of manipulation is expected. Formally, this second hypothesis states:

Hypothesis 2 In Spain, the ability of accruals to predict future cash flows is significantly constrained in situations where a high level of accounting manipulation is expected.

\section{Research design}

\subsection{Methodological approach}

To analyze the value relevance of accruals for the prediction of future cash flows, we compare two different regression models: the current cash flows model (CFM, model 1) and the accrual-based model (ABM, model 2). Future cash flows are the dependent variable in both models. Cash flows projections extend up to 4 years ahead. ${ }^{11}$ We measure current and future cash flows in their operating version. We calculate operating cash flows in year $t\left(\mathrm{OCF}_{t}\right)$ from the expression:

$$
\mathrm{E}_{t}=\mathrm{OCF}_{t}+\text { Total Accruals }
$$

If we substitute the five accruals components suggested by Barth et al. (2001) for Total Accruals, we have:

$$
\mathrm{E}_{t}=\mathrm{OCF}_{t}+\Delta \mathrm{INV}_{t}+\Delta \mathrm{RE}_{t}-\Delta \mathrm{AP}_{t}-\Delta \mathrm{OCL}_{t}-\mathrm{DEP}_{t}
$$

Consequently,

$$
\mathrm{OCF}_{t}=\mathrm{E}_{t}-\Delta \mathrm{INV}_{t}-\Delta \mathrm{RE}_{t}+\Delta \mathrm{AP}_{t}+\Delta \mathrm{OCL}_{t}+\mathrm{DEP}_{t}
$$

where,

$\mathrm{E}_{t}=$ net(after tax) earnings before extraordinary items in year $t$;

$\Delta \mathrm{INV}_{t}=$ changes in inventory in year $t$;

$\Delta \mathrm{RE}_{t}=$ changes in accounts receivable in year $t$;

\footnotetext{
11 The FASB/IASB do not specifically address the time period over which future cash flows should be predicted for accounting information to fulfil the objective of financial reporting. Different prediction horizons have been studied in the literature, that include just 1 year, 1-2 years and even 1-5 years. Barth et al. (2001) also limit their analysis to a 1-year-ahead cash flows effect but they complement their paper with sensitivity cash flows prediction tests up to 4 years ahead, obtaining results consistent with those for 1 year.
} 
$\Delta \mathrm{AP}_{t}=$ changes in accounts payable in year $t ;$

$\Delta \mathrm{OCL}_{t}=$ changes in other current liabilities in year $t$;

$\mathrm{DEP}_{t}=$ amortization and depreciation expenses in year $t$.

As for the independent variables, the first model (CFM, model 1) includes exclusively the current operating cash flows and it is taken as our benchmark for the comparison. The second model (ABM, model 2) adds total accruals to the content of the first. We estimate this second model twice. First we allow only one coefficient for total accruals (model 2a) and second we disaggregate them into the five different components mentioned above (model $2 \mathrm{~b}$ ).

If accruals fulfil their role, both these versions of model 2 should have a better predictive ability than model 1 . Obtaining a greater increase in this predictive ability with model $2 \mathrm{~b}$ than with model $2 \mathrm{a}$ will show the benefits of accruals' disaggregation. Formally, models 1, 2a and $2 \mathrm{~b}$ are:

$$
\begin{aligned}
\frac{\mathrm{FOCF}_{t+1}}{\mathrm{SALES}_{t}}= & \alpha 0+\alpha 1 \frac{\mathrm{OCF}_{t}}{\mathrm{SALES}_{t-1}}+\varepsilon_{t} \quad(\mathrm{CFM}, \text { model 1) } \\
\frac{\mathrm{FOCF}_{t+1}}{\mathrm{SALES}_{t}}= & \alpha 0+\alpha 1 \frac{E_{t}}{\mathrm{SALES}_{t-1}}+\varepsilon t \quad(\mathrm{ABMa}, \text { model 2a) } \\
\frac{\mathrm{FOCF}_{t+1}}{\mathrm{SALES}_{t}}= & \alpha 0+\alpha 1 \frac{\mathrm{OCF}_{t}}{\mathrm{SALES}_{t-1}}+\alpha 2 \frac{\Delta \mathrm{INV}_{t}}{\mathrm{SALES}_{t-1}}+\alpha 3 \frac{\Delta \mathrm{RE}_{t}}{\mathrm{SALES}_{t-1}} \\
& +\alpha 4 \frac{\Delta \mathrm{AP}_{t}}{\mathrm{SALES}_{t-1}}+\alpha 5 \frac{\Delta \mathrm{OCL}_{t}}{\mathrm{SALES}_{t-1}}+\alpha 6 \frac{\Delta \mathrm{DEP}_{t}}{\mathrm{SALES}_{t-1}}+\varepsilon t \quad(\mathrm{ABMd}, \operatorname{model} 2 \mathrm{~b})
\end{aligned}
$$

where,

$\mathrm{CFM}=$ Cash flows model;

$\mathrm{ABMa}=$ Accrual-based model, aggregated;

ABMd = Accrual-based model, disaggregated;

$\mathrm{FOCF}_{t+i}=$ Future operating cash flows for the $(t+1$ to $t+i)$ prediction period.

We compute each period-ahead operating cash flows as the mean yearly operating cash flows for all years in the period. $\mathrm{FOCF}_{t+i}$ is the mean yearly OCF generated during the period starting in $t+1$ and ending in $t+i$, where $i$ ranges from 1 to $4 .^{12}$

We scale all variables by the prior period total sales. We use total sales instead of total assets because, as evidenced by Dechow (1994), the intensity of the operating cycle affects both net operating assets and the association between earnings and operating cash flows. Companies with large operating cycles inherently present low operating cash flows and high total assets, so long-cycled companies will tend to have low values of the estimation errors as a consequence of the inherent behaviour of both the numerator $(\mathrm{OCF})$ and denominator (total assets) in the dependent variable. ${ }^{13}$

\footnotetext{
12 For example: $\mathrm{FOCF}_{t+4}=\left(\mathrm{OCF}_{t+1}+\mathrm{OCF}_{t+2}+\mathrm{OCF}_{t+3}+\mathrm{OCF}_{t+4}\right) / 4$.

13 Untabulated results show that, if we use total assets as the scaling variable, the estimations with a higher $R^{2}$ present a higher value in their estimation errors.
} 
As we said in Sect. 2, many papers follow an association-based methodology to test the role of accruals for the prediction of future cash flows. Superiority in goodness of fit tests in the estimations (e.g. $R^{2}$ ), however, does not necessarily translate into superiority in predictive ability. The functional relationship may change over time and, therefore, the association found in year $t$ may not be useful in making out-ofsample predictions in year $t+i$. To solve this problem we apply an out-of-sample methodology. Its implementation requires estimating in-sample coefficients in a first (estimation) period and then applying them in a subsequent (holdout) period so as to obtain the predictive values. We carry out our estimations cross-sectionally by year and industry.

\subsection{Absolute prediction errors}

To test the increase in predictive ability brought about by the inclusion of accruals (Hypothesis 1), we compare the absolute prediction errors of the two models (CFM and ABM). Following Brochet et al. (2008), we calculate absolute prediction errors as the absolute value of the difference between the actual and predicted values of future operating cash flows for each prediction period $\left(\mathrm{FOCF}_{t+i}\right)$. Mathematically, the absolute prediction errors can be expressed as follows:

$$
\mathrm{ABSE}_{j, t+i}=\left|\mathrm{FOCF}_{j, t+i}-\overline{\mathrm{FOCF}}_{j, t+i}\right|
$$

The subscript $j$ indicates the model ( $j=1,2 \mathrm{a}$ or $2 \mathrm{~b}$ ) used to compute the predicted value of $\overline{\text { FOCF}}$. We compare mean and median absolute prediction errors in pairs using the $t$ test statistic for the means and the Wilcoxon signed test for the medians.

\subsection{Multivariate regression analysis}

Our second hypothesis tests whether, after controlling for some business determinants, the role of accruals for the prediction of future cash flows is significantly moderated in firm-specific situations with a higher level of expected manipulation. To do so, and continuing with the error prediction methodology, we specify the following multivariate regression:

$$
\begin{aligned}
\operatorname{ABSE}_{1, t+\mathrm{i}}-\mathrm{ABSE}_{2 \mathrm{~b}, t+i}= & \beta_{0}+\beta_{\mathrm{x}} \text { EXPECTED MANIPULATION }_{t} \\
& +\beta_{\mathrm{y}} \mathrm{CONTROLS}_{t}+\varepsilon_{t} \quad(\operatorname{model} 3)
\end{aligned}
$$

where, tion;

$\beta_{\mathrm{x}}: \beta_{1}$ to $\beta_{4}=$ coefficients for the four variables proxying for expected manipula-

$\beta_{\mathrm{y}}: \beta_{5}$ to $\beta_{10}=$ coefficients for the six control variables. 


\subsection{Dependent variable}

$\mathrm{ABSE}_{1}-\mathrm{ABSE}_{2 \mathrm{~b}}$ is the dependent variable in the model. We obtain it as the difference between the absolute prediction error using the cash flows model (CFM, model 1) and the same error using the disaggregated accrual-based model (ABMd, model 2b). This dependent variable measures the extent to which accruals improve on current cash flows in predicting future cash flows. ${ }^{14}$ The greater the value of the difference, the greater the improvement provided by the accruals model (model $2 \mathrm{~b}$ ) compared to the isolated cash flows model (model 1). The multivariate model is estimated for each $(t+1$ to $t+i)$ prediction period, where $i=1 \ldots 4$.

\subsection{Explanatory variables: expected manipulation}

The literature highlights a wide variety of situations where managers are especially prone to engage in accruals manipulation. Among these, we choose four firm-specific circumstances that are particularly suitable for the Spanish environment, namely, small size, privately held, the need for new finance and the level of subjectivity of accruals.

\subsubsection{Small firm size (SIZE)}

There are several reasons to expect that small and medium-sized firms engage in more accruals manipulation than their larger counterparts. Large firms are exposed to greater political and reputation costs, have stronger internal controls and tend to hire high quality auditors. Their accruals are usually more permanent and they have greater incentives to use them to convey private information (Gill de Albornoz and Illueca 2007). Small client size is also an important attribute that leads banks to disregard the financial reports as a source of information in their credit-granting decisions. These arguments lead us to expect a positive effect of firm size on the ability of accruals to predict future cash flows. We measure the firm size variable (SIZE) as the natural logarithm of total assets.

\subsubsection{Privately held (PRIV)}

Public firms use a wider range of corporate governance mechanisms than private ones and are also under the supervision of the market authorities. In Spain, except for statutory auditing, which is compulsory for firms above a certain size (Audit Law 1988), specific corporate governance instruments (e.g. audit committees) have been implemented recently and only for public firms (see Finance Law 2002). There is evidence of a constraining effect of these instruments on earnings manipulation in Spain (García Lara et al. 2007). Further, unlike the Anglo-Saxon countries, Spanish public companies are not under so much pressure to live up to the market's expectations and, consequently, to make use of income-increasing manipulation to do so. As we do

\footnotetext{
14 We choose the ABMd as, following Barth et al. (2001), it is expected to better represent the value relevance of accruals than the ABMa.
} 
with small firms, we predict that private firms will engage in accruals manipulation to a greater extent. We analyze public companies and large ones separately because, although firms quoting on the Spanish Stock Exchange are predominantly large, most big companies in Spain are still privately held. We use a PRIV dummy variable that equals 1 if the firm is privately held (does not quote on the Spanish stock market), and 0 otherwise.

\subsubsection{Need for New Finance (NNF)}

Uncomfortably high debt levels make it difficult for a company to secure additional cash to finance its new commitments. In bank-dependent/weakly-protected countries like Spain, banks often structure debt as short term. This allows them to review their credit terms on a more frequent basis and encourages borrowers to engage in the necessary manipulation to avoid violating the covenants on which these terms are based. Gupta et al. (2008) empirically find that short-term debt induces greater earnings management and that this is a common behaviour in countries with weak legal regimes. The bankruptcy literature also highlights a high leverage (especially in the short term) as a symptom of impending failure and, consequently, as a clear incentive for manipulation. Following these arguments, we expect that the higher the level of short-term debt, the lower the ability of accruals to predict future cash flows. We use the NNF variable to proxy for short-term indebtedness which we calculate as the ratio of short-term to long-term banking debt.

\subsubsection{The level of subjectivity of accruals (SUB)}

Subjective accruals provide managers with better opportunities to communicate private information but they also leave more room for discretion. Financial statement items such as inventory or receivables are affected by more arbitrary judgement and allocation problems than others (e.g. accounts payable) and, consequently, offer greater opportunities for manipulation. In fact, subjectivity has been labelled "the lifeblood of the creative accountant". Taking this into account, Richardson et al. (2005) find that the predictive ability of accruals is negatively linked to their degree of subjectivity. This leads us to posit a negative relation between the subjectivity of accruals and their ability to predict future cash flows. Following Richardson et al. (2005), we obtain a subjectivity index by dividing the absolute value of the variation in inventories and in receivables by the whole operating accruals' structure of the firm (absolute value of the variation in inventories, receivables and payables).

\subsection{Control variables}

As in Francis et al. (2005) we include certain additional variables to control for the innate behaviour of accruals, that is, the behaviour driven by the firm's business model and operating environment. 


\subsubsection{Growth (GRW)}

In the growth stage, sales increase faster than average, as do the necessary investments in production facilities. Cash flows are more volatile increasing the need of accruals to correct timing and mismatching problems. Dechow (1994) in the US and Charitou (1997) in the UK empirically find that accruals reflect more value-relevant information in growing firms. We measure our growth variable (GRW) as sales in year $t$ minus sales in year $t-1$ divided by sales in year $t-1$.

\subsubsection{Cash-flows volatility (VOL)}

Cash receipts and disbursements generally suffer from a lack of coordination and yield a noisy measure of firm performance with disproportionate variability. As the main purpose of accruals is to solve these mismatching problems (Dechow 1994), the higher the variability of cash flows, the higher will be the improvement in predictive ability after the inclusion of accruals. We measure the cash flows volatility variable (VOL) as the firm-year OCF minus the median OCF for the whole sample period. OCF values are scaled by total sales.

\subsubsection{Operating cycle and industry (IND)}

There is a general consensus in the literature that the increased predictive ability of accruals has a positive relationship with the firms' operating cycle (Dechow 1994; Charitou 1997). The literature also agrees that the operating cycle is inherently linked to the industry sector in which the firm operates. We include four dummy variables to control for five industrial sectors: $\mathrm{IND}_{1}=$ energy and water; $\mathrm{IND}_{2}=$ manufacturing; $\mathrm{IND}_{3}=$ wholesale trade and $\mathrm{IND}_{4}=$ services. The fifth one, construction, is taken as the industry of reference because of its especially long operating cycle.

In its extended version, model 3 is as follows:

$$
\begin{aligned}
\mathrm{ABSE}_{1, t+i}-\mathrm{ABSE}_{2 \mathrm{~b}, t+i}= & \beta_{0}+\beta_{1} \mathrm{SIZE}_{t}+\beta_{2} \mathrm{PRIV}_{t}+\beta_{3} \mathrm{NNF}_{t}+\beta_{4} \mathrm{SUB}_{t}+\beta_{5} \mathrm{GRW}_{t} \\
& +\beta_{6} \mathrm{VOL}_{t}+\beta_{7 \text { to }} \beta_{10} \mathrm{IND}_{1 \text { to } 4}+\varepsilon_{t}
\end{aligned}
$$

\subsection{Sample}

We take data for the analysis from the Sabi data base, the Spanish section of Amadeus from Bureau van Dijk, which provides standardized financial statements for a large set of Spanish private and public companies. Our sample consists of all the available industrial and commercial firms from the period 1997-2003. As we are interested in analyzing the predictive ability of accruals, we separate the total sample into two periods: an estimation period (in-sample estimations) and a holdout period (out-ofsample predictions). We use the 1997-2001 period to estimate in-sample coefficients for the models under comparison (cash flows model and accrual-based model). We use the holdout 2002-2003 period to obtain 1 to 4-years-ahead cash flows predictions 
$\left(\mathrm{FOCF}_{t+i}\right)$ and their corresponding absolute prediction errors $\left(\mathrm{ABSE}_{j, t+i}\right)$ after comparison with cash flows values. As private firms must fulfil the same statutory audit requirements as public firms in Spain (external audit is compulsory for all firms above a certain size), we require that firms in our sample include an audit report together with their financial statements. Our sampling criterion provides an estimation sample of 14,002 firm-year observations and a holdout sample of 7,428 firm-year observations. Due to missing data, the number of FOCF observations falls slightly as the length of the prediction period increases, ranging from 7,426 for the period comprising only $t+1$ to 6,907 for the 4-year period ending in $t+4$. Most of these observations belong to privately-held companies. We trim both samples to exclude the $1 \%$ of the observations with the highest and lowest values of some variables depending on the model estimated.

\section{Results}

In Table 1 we present the descriptive statistics for the variables used in the analysis. Average OCF is positive (mean $=0.062$ ) and clearly higher than average Earnings (mean $=0.041$ ) which is in line with prior US evidence. The reason for this is the negative effect of amortization and depreciation (mean $=0.037)$ which is well above the positive mean value of short-term accruals (mean $=0.016) .{ }^{15}$ Also as expected, OCF shows a much higher volatility than earnings (std. dev. 0.149 vs. 0.084 ), which is consistent with Dechow (1994) when she says that OCF suffers from more timing and mismatching problems, making it a less stable indicator. The firms in our sample show great heterogeneity in size (total assets equal 6, 10 and 21 million euros) for Q25, median and Q75, respectively) and a substantial use of the short term in their banking debt requests (mean $\mathrm{NNF}=1.26)$. Average growth is almost $9 \%$ (mean GRW $=0.083$ ) and subjective accruals account for an average $63 \%$ of all operating accruals.

Table 2 shows how models $1,2 \mathrm{a}$ and $2 \mathrm{~b}$ fit average 1 to 4 years-ahead operating cash flows in the estimation period. All three models are well specified and produce significant $\mathrm{F}$ statistics. Confirming previous results, and for all future cash flows projections (columns $\mathrm{FOCF}_{t+1}$ to $\mathrm{FOCF}_{t+4}$ ), the two accrual-based models ( $2 \mathrm{a}$ and $2 \mathrm{~b}$ ) explain the future cash flows clearly better than the cash flows model (CFM, model 1: Adj. $\left.\quad R^{2}=0.081-0.197\right)$. Moreover, in all cases, the disaggregated accruals specification suggested by Barth et al. 2001 ( $A B M d$, model 2b: Adj. $R^{2}=0.294-0.468$ ) has substantially more explanatory power than the aggregated one (ABMa, model $2 a$, Adj. $R^{2}=0.135-0.225$ ). The likelihood ratio test for nested models (panel B) also shows that the above differences are statistically significant at the one percent level. These first results are consistent with the US evidence in future cash flows prediction. However, our analysis, so far, is based on associations rather than predictions.

Association tests are unable to help investors make future cash flows predictions. In fact, the usefulness of the previous estimations lies in the stability of their coefficients in different time periods and their superiority in goodness of fit does not necessarily

$\overline{15}$ Using mean values, Earnings are obtained as OCF $+\Delta$ Inventories $+\Delta$ Receivables $-\Delta$ Payables $-\Delta$ Other Current Liabilities - Amortization and depreciation. Namely: $0.0418=0.0062+0.010+0.023-$ $0.014-0.003-0.037$. Mean short-term accruals $=0.010+0.023-0.014-0.003=0.016$. 
Table 1 Descriptive statistics

\begin{tabular}{lccccr}
\hline & Mean & Median & Std. Dev. & Q25 & Q75 \\
\hline E & 0.041 & 0.030 & 0.084 & 0.009 & 0.064 \\
OCF & 0.062 & 0.048 & 0.149 & 0.001 & 0.113 \\
$\Delta$ INV & 0.010 & 0.003 & 0.060 & -0.007 & 0.023 \\
$\Delta$ RE & 0.023 & 0.014 & 0.098 & -0.016 & 0.055 \\
$\Delta$ AP & 0.014 & 0.007 & 0.082 & -0.014 & 0.035 \\
$\Delta$ OCL & 0.003 & 0.001 & 0.074 & -0.006 & 0.010 \\
AMORT & 0.037 & 0.022 & 0.050 & 0.009 & 0.048 \\
SIZE & 26.7 & 10.4 & 142.1 & 6.0 & 21.0 \\
PRIV & 0.980 & 1.000 & 0.400 & 1.000 & 1.000 \\
NNF & 1.260 & 0.938 & 1.085 & 0.485 & 1.691 \\
SUB & 0.630 & 0.586 & 0.128 & 0.526 & 0.701 \\
GRW & 0.083 & 0.064 & 0.200 & -0.017 & 0.156 \\
VOL & 0.013 & 0.000 & 0.149 & -0.048 & 0.064 \\
\hline
\end{tabular}

The total sample comprises 4,397 companies for the period 1997-2003

$E$ net earnings before extraordinary items; $O C F$ operating cash flows $\left(\mathrm{OCF}_{t}=\mathrm{E}_{t}-\Delta \mathrm{INVt}-\Delta \mathrm{RE}_{t}+\right.$ $\left.\Delta \mathrm{AP}_{t}+\Delta \mathrm{OCL}_{t}+\mathrm{DEP}_{t}\right) ; \Delta I N V$ changes in inventory; $\triangle R E$ changes in accounts receivable; $\triangle A P$ changes in accounts payable; $\triangle O C L$ changes in other current liabilities; $D E P$ amortization and depreciation expenses. The above variables have been scaled by total sales; SIZE total assets ( $€$ million); PRIV 1 if the firm is privately held (does not quote in the Spanish stock market), 0 otherwise; $N N F$ need for new finance, measured as the ratio short-term to long-term banking debt; $S U B$ subjectivity of accruals, measured using the Richardson et al.'s (2005) index; it is obtained by dividing the absolute value of the variation in inventories and in receivables by the whole operating accruals' structure of the firm (absolute value of the variation in inventories, receivables and payables); GRW growth, measured as sales in year $t$ minus sales in year $t-1$ divided by sales in year $t-1$; VOL cash flows volatility, measured as the firm-year OCF minus the median OCF for the whole sample period

translate into superiority in predictive ability. Consequently, we must apply an out-ofsample methodology (holdout period). Table 3 presents the means and medians of the absolute out-of-sample forecast errors provided by our three models (1, 2a and 2b) for each $(t+1$ to $t+i)$ future cash flows prediction period. We apply the t-test and Wilcoxon's signed test to analyze differences in the models' means and median errors, respectively, in pairs. In line with previous results, the disaggregated accrual-based model $(A B M d$, model $2 b$ ) presents significantly lower mean and median forecast errors than the other two models in all four periods (mean $=0.068,0.051,0.045$ and 0.046 for forecasting periods ending in $t+1$ to $t+4$, respectively). The aggregate model ( $A B M a$, model $2 a$ ) shows a better forecast ability than the current cash flows model (CFM, model 1), which is the worst specified according to its errors (mean 0.079, $0.062,0.056$ and 0.053 for periods ending in $t+1$ to $t+4$, respectively). Overall, Table 3 confirms that, in Spain, accrual-based accounting provides more value-relevant indicators than the primitive cash flows basis and, consequently, we cannot reject $\mathrm{H}_{1}$. Our results show that the efforts made by Spanish accounting regulators towards an increasingly sophisticated accrual-based accounting model have been worthwhile. This new evidence sheds some light on why prior priced-based findings in certain 
Table 2 Results of the association of cash flows and accrual-based models with future cash flows

\begin{tabular}{|c|c|c|c|c|}
\hline & \multicolumn{4}{|l|}{ Adjusted $R^{2}$} \\
\hline & $\mathrm{FOCF}_{t+1}$ & $\mathrm{FOCF}_{t+2}$ & $\mathrm{FOCF}_{t+3}$ & $\mathrm{FOCF}_{t+4}$ \\
\hline \multicolumn{5}{|l|}{ Panel A } \\
\hline Model 1 (CFM) & $0.081 * * *$ & $0.141 * * *$ & $0.172 * * *$ & $0.197 * * *$ \\
\hline Model 2a (ABMa) & $0.135 * * *$ & $0.199 * * *$ & $0.211 * * *$ & $0.225 * * *$ \\
\hline \multirow[t]{3}{*}{ Model 2b (ABMd) } & $0.294 * * *$ & $0.412 * * *$ & $0.459 * * *$ & $0.468 * * *$ \\
\hline & \multicolumn{4}{|c|}{$R^{2}$ Likelihood ratio test for nested models } \\
\hline & $\mathrm{FOCF}_{t+1}$ & $\mathrm{FOCF}_{t+2}$ & $\mathrm{FOCF}_{t+3}$ & $\mathrm{FOCF}_{t+4}$ \\
\hline \multicolumn{5}{|l|}{ Panel B } \\
\hline 1-2a (CFM-ABMa) & $358.87 * * *$ & $447.79 * * *$ & $375.79 * * *$ & $265.79 * * *$ \\
\hline $2 a-2 b(A B M a-A B M d)$ & $670.16^{* * *}$ & $943.43 * * *$ & $889.28 * * *$ & $794.56^{* * *}$ \\
\hline $1-2 b(C F M-A B M d)$ & $1,029.03 * * *$ & $1,391.22 * * *$ & $1,265.08 * * *$ & $1,060.33 * * *$ \\
\hline$n$ & 14,002 & 13,993 & 13,993 & 13,910 \\
\hline
\end{tabular}

Panel $A$ shows in-sample adjusted $R^{2}$ for the three models: $C F M$ the cash flows model (model 1); $A B M a$ the aggregated accrual-based model (model 2a); and $A B M d$ the disaggregated accrual-based model (model 2b). The estimation sample comprises 4,147 firms for the period 1997-2001. $\mathrm{FOCF}_{t+i}$ is the average OCF generated during the period starting in $t+1$ and ending in $t+i$, where $i$ ranges from 1 to 4 . All variables have been scaled by total sales. *** Model $\mathrm{F}$ is statistically significant at the 0.01 level

Panel $B$ shows the results for the likelihood ratio test for $R^{2}$ comparison in nested models. *** Likelihood ratio test is statistically significant at the 0.01 level

code-law European countries find such limited support for the informational value of accruals. Stock prices in these markets may not be efficiently capturing the present value of future cash flows.

Although significance on the role of accruals for future cash flows prediction has been found from an overall perspective (Hypothesis 1), there are certain firm-specific situations where opportunistic manipulation could be lowering the quality of accruals well below their desirable levels. Hypothesis 2 states that, in Spain, earnings manipulation exerts a considerable moderating effect on this role. As we apply an errors-based methodology where all determinants are simultaneously tested in the same regression, a correlation matrix is necessary to ensure the absence of multicollinearity. Table 4 shows above/below diagonal Pearson/Spearman correlation coefficients, respectively, for all the firm-specific circumstances under study. All coefficients are well below 0.5 , which means there are no serious problems of multicollinearity in our holdout sample. $^{16}$

In Table 5 we present the estimation results from model 3, which we use to test Hypothesis 2. The dependent variable is the difference between the absolute forecast errors of models 1 and $2 \mathrm{~b}\left(\mathrm{ABSE}_{1}-\mathrm{ABSE}_{2 \mathrm{~d}}\right)$. It shows the extent to which accruals improve on current cash flows in predicting future cash flows. The greater its value, the

16 The highest variance inflation factor (VIF) in the multivariate regression is 3.31 for the service industry variable, which indicates that the variables in the model are not highly collinear. 
Table 3 Paired forecast error differences between the cash flows and accrual-based models

\begin{tabular}{|c|c|c|c|c|}
\hline & \multicolumn{4}{|l|}{ Mean } \\
\hline & $\mathrm{FOCF}_{t+1}$ & $\mathrm{FOCF}_{t+2}$ & $\mathrm{FOCF}_{t+3}$ & $\mathrm{FOCF}_{t+4}$ \\
\hline \multicolumn{5}{|l|}{ Model error } \\
\hline Model 1 (CFM) & 0.079 & 0.062 & 0.056 & 0.053 \\
\hline Model 2a (ABMa) & 0.074 & 0.058 & 0.053 & 0.050 \\
\hline Model 2b (ABMd) & 0.068 & 0.051 & 0.045 & 0.046 \\
\hline \multicolumn{5}{|l|}{ Error's difference ( $t$ test) } \\
\hline 1-2a (CFM-ABMa) & $0.005 * * *$ & $0.004 * * *$ & $0.003 * * *$ & $0.003^{* * *}$ \\
\hline 2a-2d (ABMa-ABMd) & $0.006^{* * *}$ & $0.007 * * *$ & $0.008 * * *$ & $0.004 * * *$ \\
\hline \multirow[t]{3}{*}{ 1-2d (CFM-ABMd) } & $0.011 * * *$ & $0.011 * * *$ & $0.011 * * *$ & $0.007 * * *$ \\
\hline & \multicolumn{4}{|l|}{ Median } \\
\hline & $\mathrm{FOCF}_{t+1}$ & $\mathrm{FOCF}_{t+2}$ & $\mathrm{FOCF}_{t+3}$ & $\mathrm{FOCF}_{t+4}$ \\
\hline \multicolumn{5}{|l|}{ Model error } \\
\hline Model 1 (CFM) & 0.050 & 0.040 & 0.037 & 0.035 \\
\hline Model 2a (ABMa) & 0.046 & 0.037 & 0.034 & 0.033 \\
\hline Model 2d (ABMd) & 0.042 & 0.032 & 0.028 & 0.030 \\
\hline \multicolumn{5}{|c|}{ Error's difference (Wilcoxon signed test) } \\
\hline 1-2a (CFM-ABMa) & $0.004 * * *$ & $0.003 * * *$ & $0.003 * * *$ & $0.002 * * *$ \\
\hline 2a-2d (ABMa-ABMd) & $0.004 * * *$ & $0.005 * * *$ & $0.006 * * *$ & $0.003 * * *$ \\
\hline 1-2d (CFM-ABMd) & $0.008 * * *$ & $0.008 * * *$ & $0.009 * * *$ & $0.005 * * *$ \\
\hline$n$ & 7,426 & 7,346 & 7,189 & 6,907 \\
\hline
\end{tabular}

The table shows out-of-sample prediction errors for the three models: $C F M$ the cash flows model (model 1); $A B M a$ the aggregated accrual-based model (model 2a); and $A B M d$ the disaggregated accrual-based model (model 2b). The holdout sample comprises 3,933 firms for the period 2002-2003. FOCF $t+i$ is the average OCF generated during the period starting in $t+1$ and ending in $t+i$, where $i$ ranges from 1 to 4 . All variables are scaled by total sales

Significance in error differences have been tested using the $t$ test for mean differences and the Wilcoxon signed test for the medians

$*, * *, * * *$ The difference in the error between the two models is significant at the $0.10,0.05$ and 0.01 level, respectively

greater the decrease in prediction error and, hence, the better the quality of accruals. The four experimental variables (SIZE, PRIV, NNF and SUB) proxy for firm-specific circumstances identified by the literature as especially prone to manipulation. Three additional variables have been included to control for the intrinsic behaviour of accruals (GRW, VOL and IND). The table includes four columns for each of the different future cash flows prediction horizons (periods ending in $t+1$ to $t+4$ ) considered in the calculation of errors. In general, all the variables show significant coefficients in the expected direction and are robust to most future cash flows projections. The results confirm the positive effect of firm size on the quality of accruals (SIZE, $p$ value $<0.05$ in all prediction periods). Monitoring and reputation costs affect large firms in Spain giving their accruals a significantly greater forecasting ability than those of smaller firms. Also in line with our expectations, the accruals of privately- 
Table 4 Correlation matrix

\begin{tabular}{lcccccc}
\hline & SIZE & PRIV & NNF & SUB & GRW & VOL \\
\hline SIZE & & $-0.053 * * *$ & $-0.059 * * *$ & $0.058 * * *$ & 0.124 & 0.157 \\
PRIV & $-0.071 * * *$ & & $0.036 * * *$ & 0.055 & $0.014 * * *$ & -0.019 \\
NNF & $-0.035 * *$ & $0.027 * *$ & & -0.019 & $-0.131 * * *$ & $-0.319 * * *$ \\
SUB & $0.066^{* * *}$ & -0.008 & -0.003 & & $0.059 * * *$ & $0.084 * * *$ \\
GRW & $0.119 * * *$ & 0.001 & $0.027 * *$ & $0.100 * * *$ & & 0.006 \\
VOL & $0.118^{* * *}$ & $-0.046^{* * *}$ & $0.062 * * *$ & $-0.189 * * *$ & 0.010 & \\
\hline
\end{tabular}

The table shows Pearson/Spearman correlation coefficients for the holdout sample. The holdout sample comprises 3,933 firms for the period 2002-2003

SIZE $\log$ total assets; PRIV 1 if the firm is privately held (does not quote in the Spanish stock market), 0 otherwise; $N N F$ need for new finance, measured as the ratio short-term to long-term banking debt; SUB subjectivity of accruals, measured using the Richardson et al.'s (2005) index; it is obtained by dividing the absolute value of the variation in inventories and in receivables by the whole operating accruals' structure of the firm (absolute value of the variation in inventories, receivables and payables); $G R W$ growth, measured as sales in year $t$ minus sales in year $t-1$ divided by sales in year $t-1$; VOL cash flows volatility, measured as the firm-year OCF minus the median OCF for the whole sample period

$*, * *, * * *$ The coefficient is significant at the $0.10,0.05$ and 0.01 level, respectively

held firms exhibit a lower ability to predict the companies' future cash flows. As in Burgstahler et al. (2006), the negative sign of the PRIV variable, which is significant in all columns ( $p$ value $=0.000$ ) shows that, in code law countries (e.g. Spain) private firms engage in manipulation practices to a greater extent. The negative sign of the NNF variable shows that accruals experience a significant decline in predictive value as firms approach their upper level of short-term banking debt. Company directors in need of new finance exhibit a clear tendency to make use of opportunistic accounting choices to achieve their immediate targets. Following Richardson et al. (2005), we have also incorporated a variable that measures the degree of subjectivity inherent in each firm's set of accruals (SUB). Given their more arbitrary allocations, subjective accruals have been hypothesized as negatively related to reliability and, by extension, to their level of quality. Our results confirm these expectations. The higher the SUB index (percentage of the variations of inventory and receivables in the accruals of the firm), the lower the incremental contribution of accruals to the prediction of future cash flows.

In sum, the four experimental variables taken to proxy for opportunistic manipulation present significant coefficients in the expected direction. This is evidence that accounting manipulation exerts a strong constraining effect on the information value of accruals by substantially lowering their predictive ability. It is also consistent with Hypothesis 2.

Except for industry, the control variables exhibit the expected signs. For firms in the growth stage, accruals produce a significantly greater decline in the out-of-sample forecast errors as shown by the positive sign of the GRW variable. Unlike firms in financial distress, growing firms seem to make a less aggressive use of accruals. Their use comes more from the inherent needs of this business stage than from manipulation Likewise, the coefficient of the cash flows volatility variable (VOL) is also significantly positive, that is, the more volatile cash flows are, the greater the predictive ability of accruals, which is consistent with their smoothing properties. 
Table 5 Decrease in prediction errors as a function of expected accounting manipulation

\begin{tabular}{|c|c|c|c|c|c|}
\hline & \multicolumn{5}{|c|}{ Dependent variable: $\mathrm{ABSE}_{1, t+i}-\mathrm{ABSE}_{2 b, t+i}$} \\
\hline & e.s. & $\mathrm{FOCF}_{t+1}$ & $\mathrm{FOCF}_{t+2}$ & $\mathrm{FOCF}_{t+3}$ & $\mathrm{FOCF}_{t+4}$ \\
\hline Intercept & & -0.019 & -0.015 & -0.010 & -0.007 \\
\hline$p$ value & & $(0.002)$ & $(0.004)$ & $(0.035)$ & $(0.090)$ \\
\hline SIZE & $(+)$ & 0.002 & 0.002 & 0.001 & 0.001 \\
\hline$p$ value & & $(0.000)$ & $(0.000)$ & $(0.004)$ & $(0.040)$ \\
\hline PRIV & $(-)$ & -0.052 & -0.057 & -0.050 & -0.054 \\
\hline$p$ value & & $(0.000)$ & $(0.000)$ & $(0.000)$ & $(0.000)$ \\
\hline NNF & $(-)$ & -0.001 & -0.001 & 0.000 & -0.001 \\
\hline$p$ value & & $(0.008)$ & $(0.003)$ & $(0.960)$ & $(0.056)$ \\
\hline SUB & $(-)$ & -0.011 & -0.010 & -0.011 & -0.010 \\
\hline$p$ value & & $(0.009)$ & $(0.008)$ & $(0.003)$ & $(0.001)$ \\
\hline GRW & $(+)$ & 0.013 & 0.013 & 0.008 & 0.015 \\
\hline$p$ value & & $(0.000)$ & $(0.000)$ & $(0.000)$ & $(0.000)$ \\
\hline VOL & $(+)$ & 0.018 & 0.011 & 0.021 & 0.009 \\
\hline$p$ value & & $(0.000)$ & $(0.002)$ & $(0.000)$ & $(0.005)$ \\
\hline IND1 & $(-)$ & 0.018 & 0.021 & 0.010 & 0.006 \\
\hline$p$ value & & $(0.000)$ & $(0.000)$ & $(0.009)$ & $(0.087)$ \\
\hline IND2 & $(-)$ & 0.004 & 0.003 & 0.002 & 0.001 \\
\hline$p$ value & & $(0.042)$ & $(0.121)$ & $(0.156)$ & $(0.319)$ \\
\hline IND3 & $(-)$ & 0.005 & 0.004 & 0.004 & 0.000 \\
\hline$p$ value & & $(0.011)$ & $(0.013)$ & $(0.009)$ & $(0.733)$ \\
\hline IND4 & $(-)$ & 0.015 & 0.009 & 0.007 & 0.006 \\
\hline$p$ value & & $(0.000)$ & $(0.000)$ & $(0.000)$ & $(0.000)$ \\
\hline Adj. $R^{2}$ & & $2.29 \%$ & $2.09 \%$ & $1.67 \%$ & $1.88 \%$ \\
\hline$N$ & & 7,426 & 7,346 & 7,189 & 6,907 \\
\hline
\end{tabular}

$\mathrm{ABSE}_{1}-\mathrm{ABSE}_{2 \mathrm{~b}}$ is the difference between the absolute prediction error using the cash flows model (model 1) and the same error using the disaggregated accrual-based model (model $2 \mathrm{~b}$ ). The multivariate model is estimated for each $(t+1$ to $t+i)$ prediction period. FOCF $_{t+i}$ is the average FOCF generated during the period starting in $t+1$ and ending in $t+i$, where $i$ ranges from 1 to 4 . SIZE, PRIV, NNF and $S U B$ proxy for circumstances where a high level of accounting manipulation is expected. SIZE log total assets. PRIV 1 if the firm is privately held (does not quote in the Spanish stock market), 0 otherwise. $N N F$ need for new finance, measured as the ratio short-term to long-term banking debt. SUB subjectivity of accruals, measured using the Richardson et al.'s (2005) index; it is obtained by dividing the absolute value of the variation in inventories and in receivables by the whole operating accruals' structure of the firm (absolute value of the variation in inventories, receivables and payables). GRW growth, measured as sales in year $t$ minus sales in year $t-1$ divided by sales in year $t-1$. VOL cash flows volatility, measured as the firm-year OCF minus the median OCF for the whole sample period. e.s. expected sign. We include four dummy variables to control for five industrial sectors: IND1 energy and water; IND2 manufacturing; IND3 wholesale trade and IND4 services. Construction, is taken as the industry of reference 
Finally, with respect to industry, all four variables show a positive sign, which is contrary to our expectations. As construction firms, which are our reference industry, have a longer operating cycle than most other companies, accruals should play a more important role in solving the problems suffered by their mismatched cash inflows and outflows. A possible explanation for the unexpected positive sign found in the four IND variables (all industries show a better predictive ability than construction) is that book values in the construction sector failed to correctly anticipate the decline in market value suffered by their assets in the second half of this decade. ${ }^{17}$

\subsection{Robustness checks}

\subsubsection{Free cash flows}

Operating cash flows might not be the most adequate variable to capture firm value because they ignore investment cash outflows made to maintain the economic capacity of the firm (Subramanyam and Venkatachalam 2007). Using operating cash flows, firms with a greater need for long-term investments may be overvalued, unless the risk associated with their cash flows significantly reduces the value of the firm. Free cash flows represent the residual cash after these investments, so they could be a more adequate variable to measure firm value. To analyze whether our results on the forecasting behaviour of accruals and current cash flows are robust to the use of free cash flows, we have re-estimated all our models using free cash flows instead of operating cash flows predictions for each of our $t+i$ periods from $i=1$ to $4 .{ }^{18}$ Results are robust in the sense that the disaggregated accrual-based model (ABMd, model 2b) still provides significantly lower forecast errors than both the aggregate model (ABMa, model 2a) and the isolated cash flows model (CFM, model 1).

\subsubsection{Private-only firms}

Given that our main purpose is to test the role of accruals for the prediction of future cash flows in Spain, we tested our first hypothesis using the whole sample with the corresponding proportion of public and private firms. We carry out a sensitivity analysis of Hypothesis 1 after ruling out public firms and we find that accruals provide significant incremental insight into future cash flows for a sample of only private firms. As we also included the PRIV dummy variable in the multivariate model estimated to test Hypothesis 2, we are in fact providing evidence that, although significant in both groups, the quality of accruals is significantly better for public than for private firms.

\footnotetext{
17 In Spain, the construction industry has been, without a doubt, the most seriously affected by the recent worldwide downturn of the economy.

18 As the cash flows statement was not required by Spanish legislation until 2008, we calculate free cash flows as operating cash flows plus the variation of long-term assets. The SABI database provides access to the value of long-term assets at their original cost so its variation is a good proxy for investing cash flows.
} 


\subsubsection{Robust standard errors}

One of the requisites of the ordinary least squares technique used for multivariate regression is that the standard errors of the estimated coefficients are independent and identically distributed. The use of panel data sets (e.g., data sets that contain observations on multiple firms in multiple years) increase the likelihood that this requisite is not fulfilled (standard errors are biased) because the residuals might be correlated across firms (firm effect) and across time (time effect). As we use panel data to estimate the multivariate model that tests Hypothesis 2 (model 5), we consider it convenient, as an additional check, to re-estimate it assuming both (firm and time) effects are present in our sample. Following Petersen (2009), for panel data with a short-time series, the best method to obtain unbiased standard errors is to parametrically estimate the time variable and then estimate the coefficients with the standard errors clustered by firm. Our results do not change substantially after this new estimation with the exception of the private variable (PRIV), which is not significant. A possible explanation for this is that the cluster for public companies is fairly small in our sample.

\section{Summary and conclusions}

In this paper we analyze whether, in the Spanish context, accrual-based earnings are better able to predict future cash flows than current cash flows. To date most empirical evidence of an incremental value of accruals comes from Anglo-Saxon countries. However, the extension of the Anglo-Saxon empirical support for the benefits of accruals to the Spanish case is yet to be confirmed. In Spain, institutional differences lead to different agency problems and call into question the interest of accounting information for external users. Furthermore, the role of accruals for the prediction of future cash flows is bound to differ across public and private firms and, although the former are likely to be more similar to Anglo-Saxon firms, most Spanish companies are privately held. The Spanish reporting system is especially interesting for this research purpose. While the accounting model took advantage of its adaptation to the EU Directives to approach the Anglo-Saxon model, enforcement mechanisms are still poor in Spain. Motivated by the lack of empirical evidence, the primary purpose of our study is to provide Spanish investors with empirical evidence on the informational value of accruals.

Using a sample of 4,397 companies (mostly privately held), we estimate in-sample regressions of future cash flows on isolated current cash flows (model 1) and on accruals-based earnings (model 2) and we subsequently test for differences in the outof-sample prediction errors between the two models. Overall, our results are consistent with the argument that accruals add relevant information for the prediction of future cash flows, that is, that errors provided by an accrual-based model are significantly lower than those obtained with isolated cash flows. This predictive ability increases if we include accruals in the disaggregated fashion (five components) suggested by Barth et al. (2001).

As a second hypothesis, we argue that, after controlling for the effect of some business fundamentals, the role of accruals for future cash flows prediction is severely constrained by accounting manipulation. To provide evidence of this, we estimate a 
multivariate model that regresses the decrease in prediction errors brought about by the addition of accruals on a set of firm-specific circumstances where a high degree of manipulation is expected. For each of the variables used to proxy for these circumstances (small firm size, privately held, the need for new finance and the subjectivity of accruals) prediction errors decrease significantly in the hypothesized direction. The main contribution of the paper is to provide empirical evidence of the incremental ability of accruals to predict future cash flows in Spain. We do this using out-ofsample tests and not mere association tests. Further, we find that the role of accruals for future cash flows prediction is seriously lowered by earnings manipulation. Our results, then, have important implications for Spanish users, auditors and regulators as they highlight the need to strengthen the enforcement of accounting standards.

Acknowledgments The authors want to thank the reviewers for their detailed and helpful comments on the previous versions of the manuscript. This study has been carried out with the Financial support of the Government of Navarra (Ayudas a proyectos de investigación, convocatoria 2007) and from the Ministry of Science and Innovation (ECO2010-21627).

Open Access This article is distributed under the terms of the Creative Commons Attribution License which permits any use, distribution and reproduction in any medium, provided the original author(s) and source are credited.

\section{References}

Al-Attar A, Hussain S (2004) Corporate data and future cash flows. J Bus Financ Account 31(7-8):861-903

Ansón JA, Arcas Pellicer MJ, Labrador Barrafón M (1997) Análisis de la información contable en la evaluación de riesgos por entidades financieras. Revista Española de Financiación y Contabilidad XXVI(92):777-803

Arnedo L, Lizarraga F, Sanchez S (2007) Does public/private status affect the level of earnings management in code-law contxt outside the United States? A study based on the Spanish case. Int J Account 42(3):305-328

Audit Law (1988) Act 19/1988 of 12th July on auditing

Barth M, Cram D, Nelson K (2001) Accruals and the prediction of future cash flows. Account Rev 76:27-58

Brochet F, Nam S, Ronen J (2008) The role of accruals in predicting future cash flows and returns. Working paper. Harvard University

Burgstahler D, Hail LM, Leuz C (2006) The importance of reporting incentives: earnings management in European private and public firms. Account Rev 81(5):983-1016

Charitou A (1997) The role of cash flows and accruals in explaining security returns: evidence of the UK. Eur Account Rev 6(4):629-652

Dechow PM (1994) Accounting earnings and cash-flows as measures of firm performance. The role of accounting accruals. J Account Econ 18:3-42

Finance Law (2002) Law 44/2002, of 22nd November, on measures for the reformation of the Financial System

Financial Accounting Standards Board (FASB) (1978) Objectives of financial reporting by business enterprises. Statement of financial accounting concepts no.1. FASB, Stamford

Francis J, LaFond R, Olsson P, Schipper K (2005) The market pricing of accruals quality. J Account Econ 39(2):295-327

Gabás F, Apellániz P (1994) Capacidad predictiva de los componentes del beneficio: flujos de tesorería y ajustes corto-largo plazo. Revista Española de Financiación y Contabilidad 78:107-142

Gallén L, Giner B (2005) La alteración del resultado para evitar pérdidas y descensos: Evidencia empírica. Revista Española de Financiación y Contabilidad 34(124):141-181

García Lara JM, García Osma B, Penalva F (2007) Board of directors' characteristics and conditional accounting conservatism: Spanish evidence. Eur Account Rev 16(4):727-755

Gill de Albornoz B, Alcarria JJ (2003) Analysis and diagnosis of income smoothing in Spain. Eur Account Rev 12(3):443-464 
Gill de Albornoz B, Illueca M (2007) La calidad de los ajustes por devengo no afecta al coste de la deuda de las pymes españolas. Investigaciones Económicas XXXI(1):79-117

Giner B, Sancho A (1996) Análisis dinámico de la capacidad de los flujos de fondos para determinar los futuros flujos de caja. Revista Española de Financiación y Contabilidad 86:9-34

Gupta M, Khurana I, Pereira R (2008) Legal inforcement, short maturity debt, and the incentive to manage earnings. J Law Econ 51:619-639

Hung M (2001) Accounting standards and value relevance of financial statements: an international analysis. J Account Econ 30:401-420

Íñiguez R, Poveda F (2008) Persistencia del resultado contable y sus componentes: implicaciones de la medida de ajustes por devengo. Revista Española de Financiación y Contabilidad XXXVII(137): 31-33

International Accounting Standard Board (1989) Framework for the preparation and presentation of financial statements. International Accounting Standard Board, IASB, London

Kim M, Kross W (2005) The ability of earnings to predict future operating cash flows has been increasing, not decreasing. J Account Res 43:753-780

La Porta R, Lopez-de-Silanes F, Shleifer A, Vishny R (1998) Law and finance. J Political Econ 106(6):1113-1155

Leuz C, Nanda D, Wysocki PD (2003) Earnings management and investor protection. An international comparison. J Financ Econ 69:505-527

Lev B, Siyi L, Sougiannis T (2009) The usefulness of accounting estimates for predicting cash flows an earnings. Working paper, New York University, University of Illinois at Urbana-Champaign

Lizarraga F (1997) Los flujos de tesorería en la predicción del fracaso empresarial. Actualidad Financiera 4(abril):73-94

Mora A, Sabater A (2008) Evidence of income-decreasing earnings management before labour negotiations within firms. Investigaciones Económicas 32(2):201-230

Oliveras E, Puig X (2005) Tax and financial reporting in Spain. Account Eur 2:195-207

Petersen ME (2009) Estimating standard errors in finance panel data sets: comparing approaches. Rev Financ Stud 22(1):435-480

Richardson S, Sloan R, Soliman M, Tuna I (2005) Accrual reliability, earnings persistence and stock prices. J Account Econ 39:437-485

Ruiz E, Gómez N, De Fuentes C, García MA (2004) Audit quality and the going-concern decision-making process: Spanish evidence. Eur Account Rev 13(4):597-620

Subramanyam KR, Venkatachalam M (2007) Earnings, cash flows, and ex post intrinsic value of equity. Account Rev 82:457-481

Yoder T (2007) The incremental predictive ability of accrual models with respect to future cash flows. Working paper, Mississippi State University 